\title{
CFD MODELLING OF COOLING CHANNEL GEOMETRY OF PEM FUEL CELL FOR ENHANCED THERMAL PERFORMANCE
}

\author{
S. 0. Obayopo*

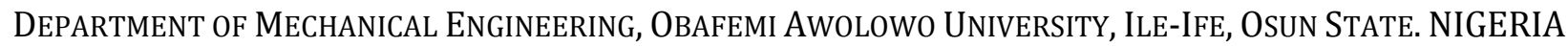 \\ E-mail address: obayopos@oauife.edu.ng
}

\begin{abstract}
Proton exchange membrane (PEM) fuel cell has many distinctive features that make it an attractive alternative clean energy source, including low start-up, high power density, high efficiency, portability and remote applications. An approach to stem the thermal build-up within the fuel cell structure that could lead to degradation of the system components is by integrating cooling channels as part of flow structure of the PEM fuel cell system. In this study, a numerical investigation was carried out to determine the impact of cooling channel geometry in combination with temperature dependent operating parameters on thermal management and overall performance of a PEM fuel cell system. The evaluation is performed using a computational fluid dynamics (CFD) code based on a finite volume approach. The systems performances are presented as a function of the system temperature, operating parameters and cooling channel geometry. The results obtained indicate that incorporating cooling channels within the fuel cell structures improves the PEM fuel cell system performance at higher temperature of operation and optimal aspect ratio of the cooling channels exist for maximised fuel cell performance for the fuel cell model considered. In addition, the parameters studied were optimized using a mathematical optimization code integrated with the CFD code.
\end{abstract}

Keywords: PEM fuel cell; Cooling channel; Aspect ratio; Optimal performance; Higher temperature; Mathematical optimisation

\section{INTRODUCTION}

A fuel cell is an electrochemical energy device that directly converts the chemical energy in the fuel into electrical energy. Applications include: portable power, stationary applications, vehicle propulsion and large electrical plants. PEM fuel cell researchers are moving ahead at a rapid pace because of the many attractive features, like rapid start-up, high power density, high efficiency and the belief of being the most promising among fuel cell types for transportation application, due to its fast start-up and dynamic response to changes in the demand for power during vehicular operations $[1-3]$. These features have made it one of the most promising clean and highly efficient power generation technologies in the $21^{\text {st }}$ century. Operating temperatures of fuel cell systems affect the maximum theoretical voltage at which a fuel cell can operate [4]. Higher operating temperatures correspond to lower theoretical maximum voltages and lower theoretical efficiency. However, higher temperature at fuel cell electrodes increases electrochemical activity which, in turn, increases efficiency [4]. Most current PEM fuel cells operate at low temperatures $\left(<80^{\circ} \mathrm{C}\right)$ encountering several performance difficulties, especially vehicular applications such as reduced electrochemical kinetics at electrode sites; flooding due to two-phase flows emergence; intolerance to impurities such as CO; insufficient heat rejection capability and relatively high cost. A recent approach is to operate this class of fuel cell at higher temperature $\left(>100^{\circ} \mathrm{C}\right.$ ) which eliminates some of these obstacles [58]. Operating at higher temperatures increases the reaction rates at both electrodes and consequently increases system efficiency. The quality of waste heat from the fuel cell stack, which could be used in other system components requiring heat or used to run an additional thermodynamic heat for additional power, is also enhanced at higher operating temperature.

Moderate temperature ranges exist within which a specific fuel cell type will operate efficiently and reliably. Subsequently, the goal in fuel cell thermal management is to ensure effective stack operation at a specified temperature range. Thermal management has a very strong impact on fuel cell performance, since it 
affects the transport of water and gaseous species as well as electrochemical reactions in the cells. Thermal management still remains a critical issue that needs to be resolved in order for PEM fuel cell technology to be feasible for various commercial applications $[9,10]$.

A number of numerical modelling works has been carried out in the literature to investigate heat/mass transfer in PEM fuel cells. Coppo et al. [11] presented a 3-D model to study the influence of temperature on PEM fuel cell operation which includes a two-phase flow in the gas distribution channel. The obtained result indicates that both liquid water transport within the gas diffusion layer (GDL) and liquid water removal from the surface of the GDL play an important role in determining variations in cell performance as far as temperature is concerned. Yan et al. [12] presented a 1D non-isothermal model to analyse the effect of anode and cathode side temperatures on the membrane water distribution. The obtained results shows that a temperature increase on the anode side can lead to membrane dehydration and fuel cell operation at high current density leads to membrane dehydration on the anode side, due to the strong electro-osmotic water drag at high current density.

Obayopo et al. [13] presented a 3-D numerical model to investigate the effect of a range of operating conditions such as reactant flow rates, GDL porosity, channel geometry and flow orientation on the performance of a single PEM fuel cell and also to determine the optimal operating conditions. One of the important outcomes of their study is that fuel cell performance increases with increase in temperature from 60 to $80^{\circ} \mathrm{C}$ at operating voltage of $0.3 \mathrm{~V}$ for the model studied. Increasing the cell temperature beyond $80^{\circ} \mathrm{C}$ result in higher levels of water loss in the cell until a critical temperature is attained where the evaporated water is greater than the amount of water being generated in the cell thereby resulting in total dry-out of the membrane. Ju et al. [14] presented a 3-D non-isothermal single-phase model for all seven layers of the PEM fuel cell that accounts for various location-specific heat-generation mechanisms. These mechanisms include irreversible heating due to electrochemical reactions and entropy, and Joule (ohmic) heating due to membrane ionic resistance. They observed that the thermal effect on PEM fuel cells becomes more critical at higher cell current density and/or lower GDL thermal conductivity. Their result further shows that temperature increase in the membrane is highly dependent on the GDL thermal conductivity and inlet humidity conditions.

A number of modelling approaches has been developed in the literature to predict the thermal effect in PEM fuel cells as described above [12-14] but, although they represent a significant contribution in fuel cell thermal modelling, there are few reports on thermal cooling approaches employing cooling channel geometry to enhance thermal management in a PEM fuel cell structure. To the author's knowledge, studies on the impact of the geometric configuration of cooling channels on effective thermal heat transfer and performance in the fuel cell system is still limited in the literature and this phenomenon is explored in this study. This paper describes a numerical modelling study that investigates the geometrical effect of cooling channels on thermal performance of a PEM fuel cell. A parametric study on the effect of temperature, stoichiometry ratio, relative humidity and the cooling channel aspect ratio on cell performance were initially conducted, since these factors contribute to the extent of membrane hydration in a fuel cell system. Optimal results of these parameters were subsequently combined with the different aspect ratio of the cooling channels and the system performance was evaluated for elevated fuel cell system temperatures (100 $150^{\circ} \mathrm{C}$ ). In addition, a mathematical optimisation tool was used to select the best geometric configuration that would improve cooling and enhance fuel cell performance for a given cooling gas flow Reynolds number. The results of this study will be of interest to fuel cell design engineers at improving thermal management in fuel cell system and enhancement of system performance.

\section{Model description}

In the present work, numerical study and optimisation of geometric parameters of the cooling channel of a PEM fuel cell is attempted, based on a threedimensional full cell model, and the impact on cell performance is explored. Fig. 1 shows the 3-D schematic of the model of the PEM fuel cell system. The influential factors considered in this study that impacts on the fuel cell thermal behaviour and subsequently performances are the stoichiometry ratio, the relative humidity, the coolant air Reynolds number and the cooling channel aspect ratio. These parameters are selected as the design parameters to be optimised in this study. The construct of three (3) cooling channels transversely arranged at equal distances at each side (anode and cathode) of the bipolar plates of the PEM fuel cell are also shown in Fig. 1. The other physicochemical properties for the fuel cell system are kept constant in this study and given in Table 1.

The Dynamic-Q optimisation algorithm [15] is employed herein as the optimisation search scheme. This study is aimed at optimising these identified 
factors, so that the best performance in terms of the optimal current density (the objective function) of the PEM fuel cell system at prescribed operating conditions can be achieved. The optimisation algorithm is expected to ensure robust optimal values for the factors investigated in this study.

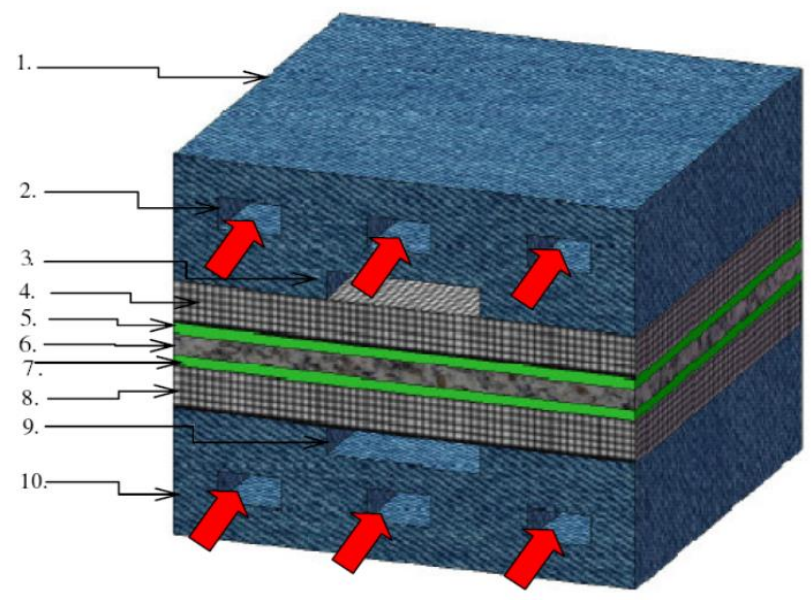

Figure 1. A schematic diagram of a 3-D model of PEM fuel cell system with cooling channels embedded in the bipolar plates
1. Anode-side bipolar plate
2. Cooling channel
3. Hydrogen fuel channel
4. Anode GDL
5. Anode catalyst layer

6. Membrane

7. Cathode catalyst layer

8. Cathode GDL

9. Air gas channel

10.Cathode-side bipolar plate

Table 1.Parameters and properties used in the present model.

\begin{tabular}{ll}
\hline \multicolumn{1}{c}{ Description } & Value \\
\hline Cell operating temperature $\left({ }^{\circ} \mathrm{C}\right)$ & 70 \\
$\begin{array}{l}\text { Air-side/fuel-side inlet pressure } \\
\text { (atm) }\end{array}$ & $3 / 3$ \\
Open-circuit voltage $(\mathrm{V})$ & 0.95 \\
Porosity of gas diffuser layer & 0.4 \\
Permeability of gas diffuser layer & $1.76 \times 10^{-11}$ \\
$\left(\mathrm{~m}^{2}\right)$ & 1.5 \\
Tortuosity of gas diffuser layer & 0.4 \\
Porosity of catalyst layer & $1.76 \times 10^{-11}$ \\
Permeability of catalyst layer $\left(\mathrm{m}^{2}\right)$ & 1.5 \\
Tortuosity of catalyst layer & 0.28 \\
Porosity of membrane & $1.8 \times 10^{-18}$ \\
Permeability of membrane $\left(\mathrm{m}^{2}\right)$ & $0.915 \times 10^{-4}$ \\
Reference diffusivity of $\mathrm{H}_{2}\left(\mathrm{~m}^{2} \mathrm{~s}^{-1}\right)$ & $0.22 \times 10^{-4}$ \\
Reference diffusivity of $\mathrm{O}_{2}\left(\mathrm{~m}^{2} \mathrm{~s}^{-1}\right)$ & 190 \\
Electric conductivity of catalyst & \\
layer $\left(\Omega^{-1} m^{-1}\right)$ & 300 \\
Electric conductivity of GDL & 4000 \\
$\left(\Omega^{-1} m^{-1}\right)$ & \\
Electric conductivity in carbon & \\
plate $\left(\Omega^{-1} m^{-1}\right)$ & \\
\hline
\end{tabular}

\begin{tabular}{lc}
\hline \multicolumn{1}{c}{ Description } & Value \\
\hline $\mathrm{O}_{2}$ stochiometry ratio & 1.2 \\
$\mathrm{H}_{2}$ stochiometry ratio & 2.0 \\
Oxygen mole fraction & 0.406 \\
Relative humidity of inlet fuel/air & $100 \%$ \\
Reference current density of anode & 7500 \\
Reference current density of & 20 \\
cathode $\left(\mathrm{A} / \mathrm{m}^{2}\right)$ & 0.5 \\
Anode transfer coefficient & 0.5 \\
Cathode transfer coefficient & $100 \mathrm{~s}^{-1}$ \\
Evaporation and condensation rate &
\end{tabular}

\subsection{Governing equations}

The employed governing equations are a single set applicable to all domains (flow channels, GDL and catalyst layer). This approach is based on the previous work of Um et al. [16]. The conservation equations of mass, momentum, species, proton, electron and energy are presented below:

Continuity equation:

$$
\nabla \cdot(\text { ou })=S_{m}
$$

Momentum:

$$
\frac{1}{\varepsilon^{2}} \nabla \cdot(\rho \mathrm{uu})=-\nabla p+\nabla \cdot \tau+S_{u}
$$

\section{Species:}

$\nabla \cdot\left(\mathbf{u} C_{k}\right)=\nabla \cdot\left(D_{k}^{e f f} \nabla C_{k}\right)+S_{k}$

Proton:

$\nabla \cdot\left(\kappa^{e f f} \nabla \Phi_{e}\right)+S_{\Phi}=0$

Electron:

$\nabla \cdot\left(\sigma_{s}^{e f f} \nabla \Phi_{s}\right)+S_{\Phi}=0$

Energy:

$$
\nabla \cdot\left(\rho c_{p} \mathbf{u} T\right)=\nabla \cdot\left(k^{\text {eff }} \nabla T\right)+S_{T}
$$

The energy source term, $S_{T}$, depicts the sum of the reversible heat release and the irreversible heat generation. In the catalyst layer, the reversible and irreversible reaction heats, as well as latent heat of water phase change, are considered. For the membrane, the ohm heating of the current due to the large resistance of the membrane is also considered. The transfer current densities at the anode and the cathode are calculated using the Butler-Volmer equation [17]:

$$
i_{o}=i_{o, r e f}\left\{\exp \left[\frac{\alpha_{a n} n F}{R T} \eta\right]-\exp \left[\frac{-\alpha_{c a t} n F}{R T} \eta\right]\right\}
$$




$$
\eta=\left(\Phi_{s}-\Phi_{e}\right)-E_{o c v}
$$

where $F$ is the Faraday constant, $\alpha_{a n}$ and $\alpha_{c a t}$ represents the experimental anodic and cathodic transfer coefficients, respectively, and $\mathrm{R}$ is the universal gas constant. The effective diffusivity $\left(D_{i, e f f}\right)$ for the gas-phase flow in porous media can be written as:

$$
D_{i, e f f}=D \frac{\varepsilon}{\tau}
$$

The quantity ( $\tau=$ tortuosity) is usually estimated through experiment. Therefore, it is conventionally correlated in fuel cell studies using the Bruggeman correlation [18].

This correlation assumes $\tau$ is proportional to $\varepsilon^{-0.5}$, resulting in the simpler expression [18]:

$$
D_{i, e f f}=D \varepsilon^{1.5} \text {. }
$$

The porosity correlation is used to account for geometric constraints of the porous media.

The Reynolds number was defined as [19]:

$$
\operatorname{Re}=\dot{m} D /(\mu A) \text {. }
$$

This study is modelled from low temperature of operation to higher temperature conditions, hence water vapour may condense to liquid water, especially at high current densities. The existence of the liquid water keeps the membrane hydrated, but it also blocks the GDL passage, reduces the diffusion rate and the effective reacting surface area. The water formation and transport of liquid water is modelled by using a saturation model based on [20,21]. In this approach, the liquid water formation and transport is governed by the conservation equation for the volume fraction of liquid water, $s$, or the water saturation [22]:

$\frac{\partial\left(\epsilon \rho_{I} s\right)}{\partial t}+\nabla \cdot\left(\rho_{l} \overrightarrow{V_{l}} s\right)=\gamma_{w}$

where the subscript $l$ represents liquid water, and $r_{w}$ is the condensation rate modelled as:

$r_{w}=c_{r} \max \left(\left[(1-s) \frac{P_{w w}-P_{s a t}}{R T} M_{w_{l} H_{2} o}\right],\left[-s \rho_{l}\right]\right)$

where $r_{w}$ is added to the water vapor equation as well as the pressure correction (mass source). The condensation rate constant is hardwired to $c_{r}=100 s^{-1}$. It was assumed that the liquid velocity,
$V_{p}$ is equivalent to the gas velocity inside the gas channel. Inside the highly-resistant porous zones, the use of the capillary diffusion term allows the replacement of the convective term in Eq. (12):

$$
\frac{\partial\left(e \rho_{\mathrm{I}} s\right)}{\partial t}+\nabla \cdot\left[\rho_{l} \frac{K s^{\mathrm{I}}}{\mu_{\mathrm{I}}} \frac{d p_{C}}{d s} \nabla s\right]=\gamma_{w} .
$$

Depending on the wetting phase, the capillary pressure is computed as a function of $s$ (the Leverett function) $[22,23]$ and shown at the bottom of this page:

Eq. (12) models various physical processes such as condensation, vaporisation, capillary diffusion and surface tension. The clogging of the porous media and the flooding of the reaction surface are modelled by multiplying the porosity and the active surface area by $(1-s)$, respectively.

\subsection{Numerical procedure}

The model equations were solved by using a finitevolume computational fluid dynamics code Fluent [22] with Gambit® (2.4.6) [24] as a pre-processor. The CFD code has an add-on package for fuel cells, which has the requirements for the source terms for species transport equations, heat sources and liquid water formations. The domain was discretised using a second-order discretisation scheme. The SIMPLE algorithm [25] for convection-diffusion analysis was utilised to deal with the pressure-velocity coupling. Numerical convergence was obtained at each test condition when the relative error of each dependent variable between two consecutive iterations was less than $1.0 \times 10^{-7}$. The domain was divided into hexahedral volume elements. A grid independence test was carried out to ensure that solutions were independent of the dimensions of the chosen grid with consideration for both accuracy and economics. For this purpose, five grid systems at $24 \times 12 \times 60,34 \times 12$ $\times 60,34 \times 22 \times 60,44 \times 22 \times 60$ and $34 \times 34 \times 60$ were tested. The obtained results of the average current density under different grid systems, when the PEM fuel cell system operating voltage was $0.7 \mathrm{~V}$, are summarised in Table 2.

$$
p_{c}=\left\{\begin{array}{c}
\frac{\sigma \cos \theta_{c}}{\left(\frac{K}{\varepsilon}\right)^{0.5}\left(1.417(1-s)-2.12(1-s)^{2}+1.263(1-s)^{3}\right) \text { for } \theta_{c}<90^{\circ} C} \\
\frac{\sigma \cos \theta_{c}}{\left(\frac{K}{\varepsilon}\right)^{0.5}}\left(1.417(1-s)-2.12 s^{2}+1.263 s^{3}\right) \text { for } \theta_{c}>90^{\circ} C
\end{array}\right.
$$


It was considered that the system of $34 \times 22 \times 60$ ( $I=$ $1.7054 \mathrm{~A} / \mathrm{cm}^{2}$ ) was sufficient for the present study as a trade-off between accuracy and cost of time. A typical grid network for the computational domain is shown in Fig. 2. The model and solution were implemented using an Intel ${ }^{\circledR}$ Core(TM) 2 Duo $3.00 \mathrm{GHz}$ PC with $3.24 \mathrm{~GB}$ of DDRam.

Table 2: Grid independence test

\begin{tabular}{lc}
\hline Grid size & $I_{\mathrm{av}}\left[\mathrm{A} / \mathrm{cm}^{2}\right]$ \\
\hline $24 \times 12 \times 60$ & 1.7012 \\
$34 \times 12 \times 60$ & 1.7048 \\
$34 \times 22 \times 60$ & 1.7054 \\
$44 \times 22 \times 60$ & 1.7055 \\
$34 \times 34 \times 60$ & 1.7057 \\
\hline
\end{tabular}

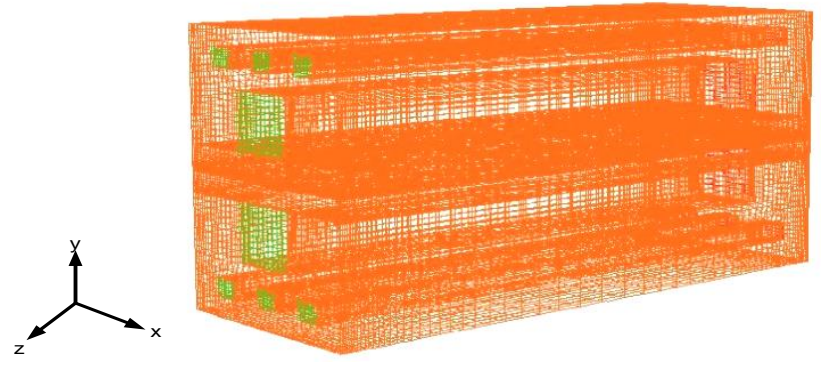

Figure 2. The discretised three-dimensional computational domain of a single PEM fuel cell with cooling channels

\section{MATHEMATICAL OPTIMISATION ALGORITHM}

The Dynamic-Q optimisation algorithm [15] was used in this study. The algorithm is a robust multidimensional gradient-based optimisation algorithm which does not require an explicit line search and is ideally robust for cases where function evaluations are computationally expensive. The algorithm applies the dynamic trajectory leap-Frog optimization code (LFOPC) which is adapted to handle constrained problems through approximate penalty function formulation [15]. This dynamic approach is applied to successive quadratic approximations of the actual optimisation problems. The use of spherical quadratic approximation in the Dynamic- $Q$ algorithm offers a competitive advantage when compared with other algorithms in terms of the computational and storage requirements [26]. Storage savings become highly significant when the number of variables becomes large. Therefore, this particular strength of the Dynamic-Q method makes it well suited for optimisation of engineering problems with a large number of variables and it has been used to successfully solve a large variety of engineering problems [27-31].

\section{Optimisation problem formulation}

The optimisation problem was tailored towards finding the best operating design parameters which would give the best performance in PEM fuel cells. The design variables which greatly affect the performance of PEM fuel cells, especially at high operating temperatures are the air stoichiometry ratio, relative humidity $(R H)$, the aspect ratio of cooling channels and the coolant Reynolds number $[12,13]$. The objective function here is the maximised current density of the fuel cell system at optimised operating factors (stoichiometry ratio, relative humidity, cooling channel aspect ratio and coolant Reynolds number). Table 3 shows the dimensions of the cooling channels used at base case condition for this study.

Table 3: Dimension of the cooling channels investigated for initial simulations.

\begin{tabular}{ccccc}
\hline Test Case & $\mathrm{W}(\mathrm{mm})$ & $\mathrm{H}(\mathrm{mm})$ & $\mathrm{L}(\mathrm{mm})$ & $\alpha(=H / W)$ \\
\hline 1 & 0.8 & 1.5 & 120 & 1.875 \\
2 & 1.2 & 3.0 & 120 & 2.500 \\
3 & 1.6 & 4.5 & 120 & 2.813 \\
\hline
\end{tabular}

The objective function for the optimisation can be written mathematically as

$$
I_{\text {max }}=f\left(\lambda_{o p t}, R H_{o p t}, H / W_{o p t}, R e\right)
$$

where $\boldsymbol{I}_{\max }$ is the maximised current density output for the optimised design variables.

\subsection{Design variables constraints}

Total fixed volume. For each of the optimisation problems, the cooling channel volume is kept constant.

The following constraints are imposed for the optimisation:

$$
1 \leq \lambda \leq 5
$$

$$
0.2 \leq R H \leq 1.0
$$

$$
1.5 \leq H / W \leq 3.5
$$

$100 \leq \operatorname{Re} \leq 500$

\section{RESULTS AND DISCUSSION}

\subsection{Model validation}

In computational modelling, grid independence study and comparison of the CFD results with experimental 
data are the prescribed metrics for validation and verification of the CFD modelling studies. For fuel cell performance description, the polarisation or voltagecurrent (IV) curve is one of the most important final outcomes of numerical simulation and is widely used for validation purposes [32]. The simulation results for the base case operating conditions were verified against experimental measurements of Wang et al. [33]. The computed polarisation curve shown in Fig. 4 is in good agreement with the experimental curves in the low load region. However, the model current density in the high mass transport limited region $\left(>1.5 \mathrm{~A} / \mathrm{cm}^{2}\right)$ is higher than the experimental values.

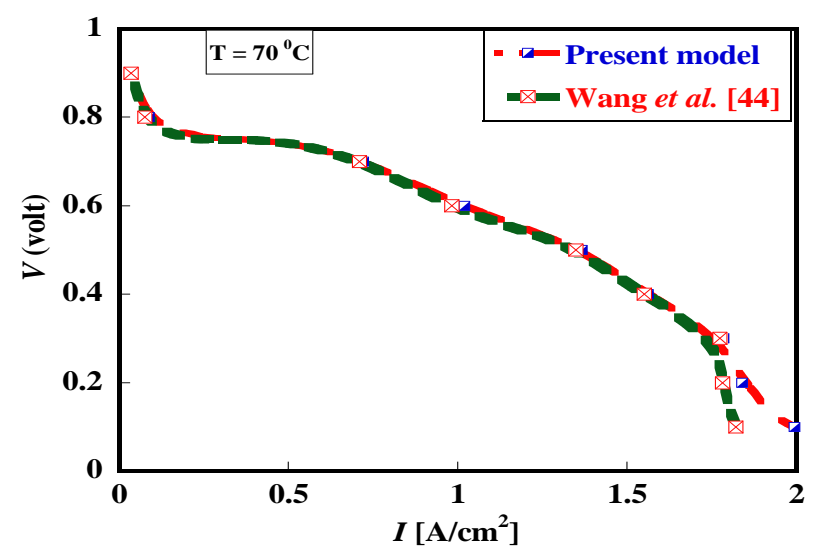

Figure 4. Comparison of numerical model prediction and experimental polarisation curves at base condition

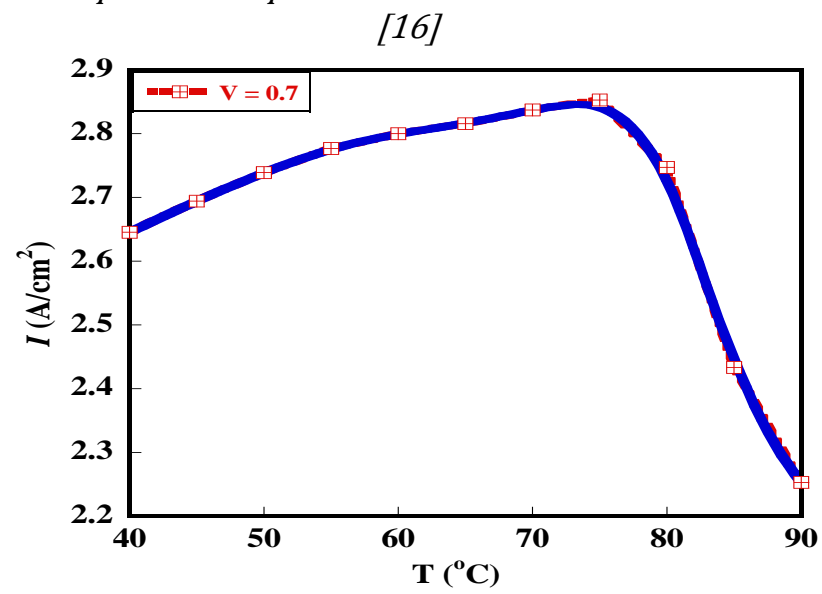

Figure 5. The cell current density as a function of temperature and the operating cell voltage

This might be due to possible experimental uncertainty or inadequate account of the effect of reduced oxygen transport, as a result of water flooding at the cathode side of the fuel cell at higher current density [34]. However, the predicted dependent variable distribution patterns could still be used successfully for better understanding of the complicated processes in fuel cell systems.

\subsection{Parametric study results}

In this section, a series of simulations was performed on a range of PEM fuel cell operating parameters to investigate their effect on the performance of the system. These parameters were investigated at operating cell voltage of $0.7 \mathrm{~V}$ and results are presented below.

First, the effect of temperature on the performance of a PEM fuel cell and the investigation of an optimal temperature range for the modelled PEM fuel cell system in this study is shown. Figure 5 shows the effect of operating temperature from $40^{\circ} \mathrm{C}$ to $90^{\circ} \mathrm{C}$ on the performance of the PEM fuel cell system. The PEM fuel performance increase with the increase in cell temperature between $40^{\circ} \mathrm{C}$ and $75^{\circ} \mathrm{C}$, since the water removal is easier and prevents incidence of flooding. The cell improvement at this temperature range is more noticeable at higher cell current density. Meanwhile, an onset of decline in performance is observed as the operating temperature is increased beyond $75^{\circ} \mathrm{C}$. Profound performance deterioration occurred at temperatures between $\approx 75^{\circ} \mathrm{C}$ and $90^{\circ} \mathrm{C}$, practically as a result of high membrane dehydration at these elevated temperatures. Optimal performance behaviour for the PEM fuel cell model is clearly depicted in this figure. This observed performance reduction phenomenon is a critical factor hindering the operation of PEM fuel cells beyond a certain temperature range to avoid fuel cell failure. Figure 6 shows the polarisation curve at a varying stoichiometry number for a constant temperature $\left(70{ }^{\circ} \mathrm{C}\right)$ and pressure ( $\mathrm{P}=3$ bar). The result shows that as the air stoichiometry ratio increased, the fuel cell performance improved gradually. The air stoichiometry increment improves the oxygen availability and the humidity of the membrane thereby improving the level of reaction on the membrane. However, if there is relatively low air flow rate in some cases, there is possibility of increase in membrane humidity which decreases the electrical resistance and thereby improves the fuel cell performance.

This stoichiometry related observation predicts the possibility of an optimum cathode stoichiometry for fuel cell systems. Figure 7 depicts the PEM fuel cell behaviour at varying stoichiometry ratios of the cathode for three different current density loads. The figure shows that, at relatively low current density of the fuel cell system $\left(0.42 \mathrm{~A} / \mathrm{cm}^{2}\right)$, the air stoichiometry has little impact on the temperature. At this low current density, the rate of fuel consumption is small and the heat generation in the fuel cell system is minimal. 


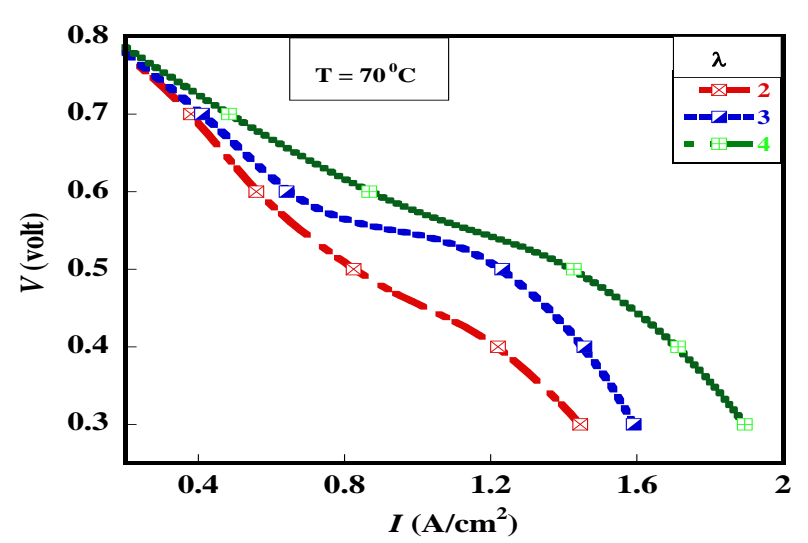

Figure 6. I-V curve at varying stoichiometry number. $P=$ 3.0 bar and $\operatorname{Re}=500$

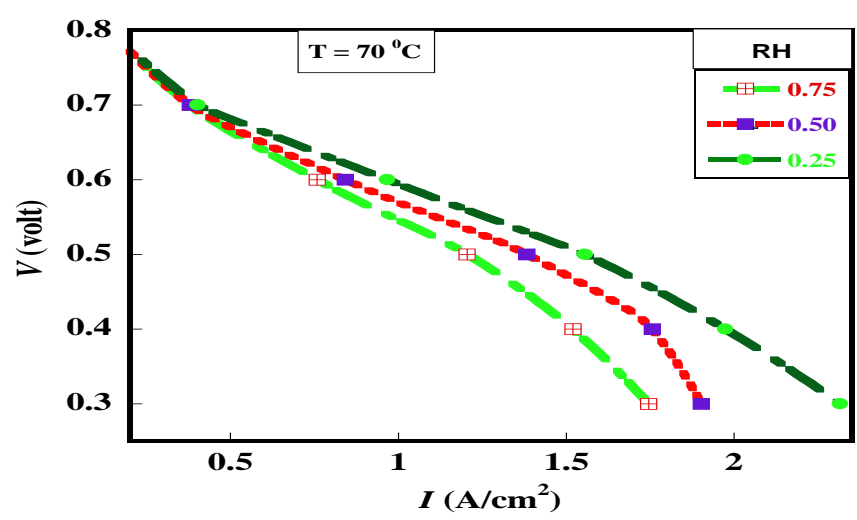

Figure 8. I-V curve at varying relative humidity $(R H) . P=$ 3.0 bar and $R e=500$

For an increased current density (i.e. $0.72 \mathrm{~A} / \mathrm{cm}^{2}$ ) of the fuel cell system, which corresponds to higher reaction rates in the fuel cell system and subsequently increases in heat generation, the effect of the stoichiometry ratio becomes glaring on the cell temperature. The increased air stream improves heat transfer in the fuel cell system. This shows the possibility of an optimal match of temperature and stoichiometry ratio for improved fuel cell system performance.

Figure 8 shows the influence of relative humidity at the cathode inlet on the fuel cell output voltage. At an increased relative humidity at the cathode inlet, air transport to the catalyst is hindered. This results in an increase in the cathode over-potential, especially at a high operating current density of the fuel cell system. There is an increase in the generation of liquid water which results in reduced PEM fuel cell performance. This result shows that the relative humidity of the cathode inlet has a significant effect on liquid water formation and the extent of heat removal within the fuel cell system. For optimal system performance, this effect could be optimised in relation to other operating parameters.

Nigerian Journal of Technology,

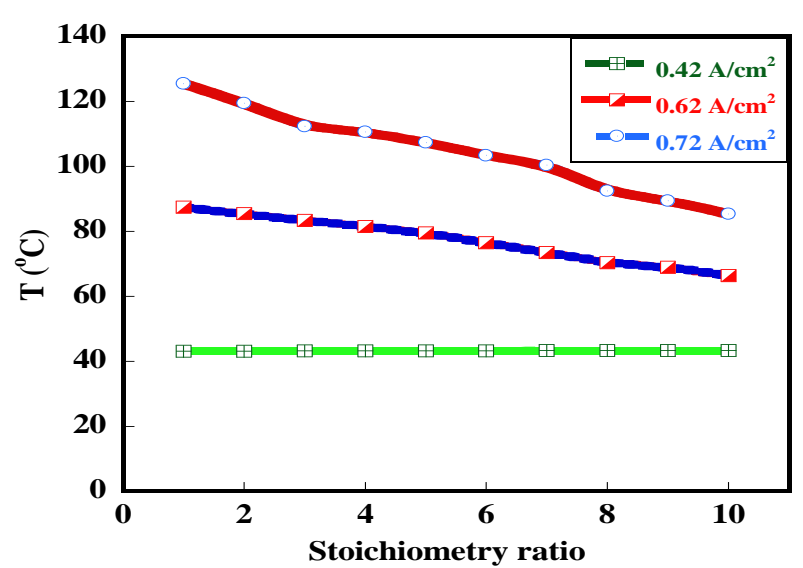

Figure 7. Effect of stoichiometry ratio on the PEM cell temperature at cell voltage of $0.7 \mathrm{~V}$

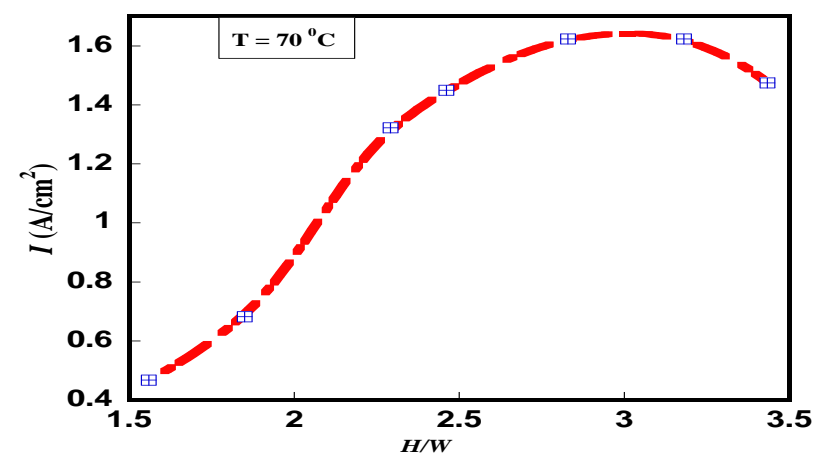

Figure 9. The cell current density at different aspect ratio at a cell potential of $0.7 \mathrm{~V}$ and a fixed Reynolds number of 500

Figure 9 shows the fuel cell performance at different aspect ratios of the cooling channels for a Reynolds number of 500. The result shows that fuel cell performance increases as the aspect ratio of the cooling channels increases to an operating temperature of $70^{\circ} \mathrm{C}$, until it reaches an optimal aspect ratio of $\approx 3.0$ $\mathrm{mm}$. Beyond the aspect ratio of about 3.0, cell performance starts to deplete. This result shows the existence of an optimal channel aspect ratio that optimises fuel cell performance in terms of current density.

Figure 10 shows the $I V$ curve for the cooling channel aspect ratios (Table 4) investigated at the base operating condition of the fuel cell. It is observed that fuel cell performance increases with the increase of the cooling channel aspect ratio at a cell operating temperature of $70^{\circ} \mathrm{C}$. This increase in performance is likely due to an improvement in the cooling within the PEM fuel cell system, thereby increasing the cell membrane hydration and subsequently positively aiding cell performance. The performance improvement is more significant at higher current density of the PEM fuel cell operation. 


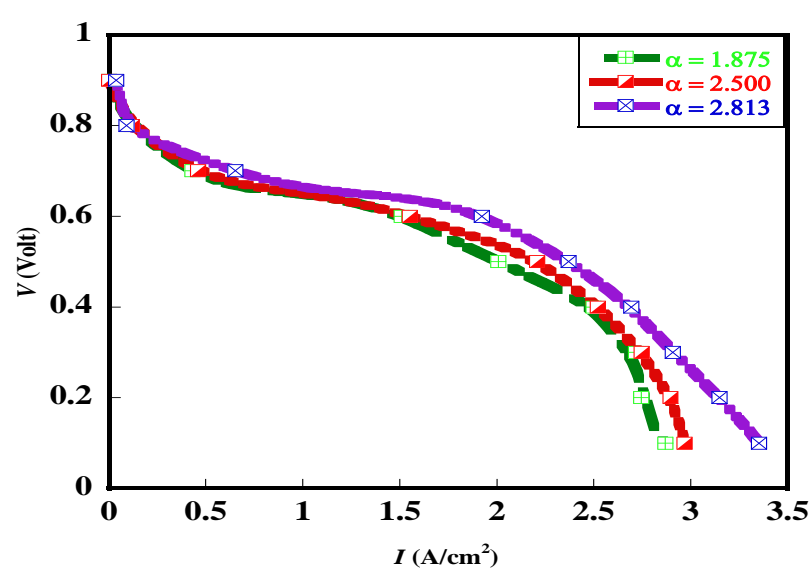

Figure 10. Current density at three cases of channel aspect ratio and $\mathrm{Re}=500$

Table 4: Values of optimised parameters

\begin{tabular}{lc}
\hline Model parameters & Optimised values (0.7V) \\
\hline$\lambda$ & 4.161 \\
$R H$ & 0.782 \\
$H / W$ & 3.182 \\
\hline
\end{tabular}

Table 5: Polarisation data at optimised conditions and varying cell operating temperatures at $\operatorname{Re}=500$.

\begin{tabular}{cccc}
\hline $\begin{array}{c}\text { Cell voltage } \\
(\mathrm{V})\end{array}$ & $\begin{array}{c}(\mathrm{T}=120 \\
\left.{ }^{\circ} \mathrm{C}\right)\end{array}$ & $\begin{array}{c}I\left(\mathrm{~A} / \mathrm{cm}^{2}\right) \\
\left.{ }^{\circ} \mathrm{C}\right)\end{array}$ & $\begin{array}{c}(\mathrm{T}=150 \\
\left.{ }^{\circ} \mathrm{C}\right)\end{array}$ \\
\hline 0.7 & 2.1132 & 2.3722 & 2.4167 \\
0.6 & 2.5611 & 2.7421 & 2.8718 \\
0.5 & 2.9621 & 3.2214 & 3.3628 \\
0.4 & 3.4821 & 3.6418 & 3.7214 \\
\hline
\end{tabular}

\subsection{Optimisation results}

The results obtained previously on the effect of the stoichiometry ratio, relative humidity and cooling channel aspect ratio on performance of the PEM fuel cells suggest the possibility of an optimal combination of these parameters for improved performance of PEM fuel cells when temperature is increased beyond the critical operating temperature which is typical of low temperature PEM fuel cells. Moreover, these factors are usually mutually dependent, especially in determining the rate of membrane hydration which, in turn, determines the reaction and transport characteristics in the fuel cell system. These factors are combined with varying cell operating temperatures to predict cell performance, especially when operation at higher temperatures (HT) is desired. It is well know that operating PEM fuel cells at higher operating temperatures eliminates some of the complications hindering improved performance. An intermediate HTPEM $\left(100-150^{\circ} \mathrm{C}\right)$ operating situation was investigated in this study. A series of numerical optimisations and calculations within the specified design constraint ranges in Section 4.1 were conducted to highlight the optimal performance of the PEM fuel cell model studied in this work. Table 4 presents the obtained optimal values for the optimised parameters using the Dynamic-Q algorithm.

The maximised fuel cell performance was investigated at varying cell operating voltage for the combination of the optimal parameters in Table 5 at higher cell operating temperatures of the fuel cell. Table 6 shows the polarisation data based on the optimal design parameters for the different operating fuel cell voltages and temperatures. The results presented in Table 5 show that there is improvement in cell performance at different cell voltages with increasing cell operating temperatures. Higher performance was obtained at low cell operating voltages compared to higher cell voltages at different temperature ranges. The increase in cell current density difference was more prominent between the temperatures of $120^{\circ} \mathrm{C}$ and $130^{\circ} \mathrm{C}$, but as temperature increased towards $150^{\circ} \mathrm{C}$, cell performance started to deplete. When the operation was conducted beyond the $150^{\circ} \mathrm{C}$ level, the cell performance reduction became highly noticeable. This is most likely due to high level membrane dehydration beyond this temperature $\left(150^{\circ} \mathrm{C}\right)$ level. The cooling to sustain the thermal build-up in the cell structure was no longer effective at this higher temperature level.

Figure 11 shows the peak current density as a function of cooling channel aspect ratio and cell temperature. An optimum cooling channel aspect ratio exists for the examined temperature ranges in which the peak fuel cell current density is maximised. This obtained result suggests that optimal arrangements of the channel geometry (aspect ratio), that could effectively maximise the cell current density of the fuel cell system, are feasible.

In Figure 12, the optimal aspect ratio is shown as a function of the coolant Reynolds number and temperatures. The figure depicts an increase in the aspect ratio of the cooling channels as the Reynolds number increases from 100 to $\approx 300$, but the rate of increment starts declining as the Reynolds number increases from 300. The result further shows that, for an increased temperature to operate the fuel cell system, the required optimal aspect ratio increases, but at a relatively lower rate due to reduced system temperature as the coolant Reynolds number is increased. 


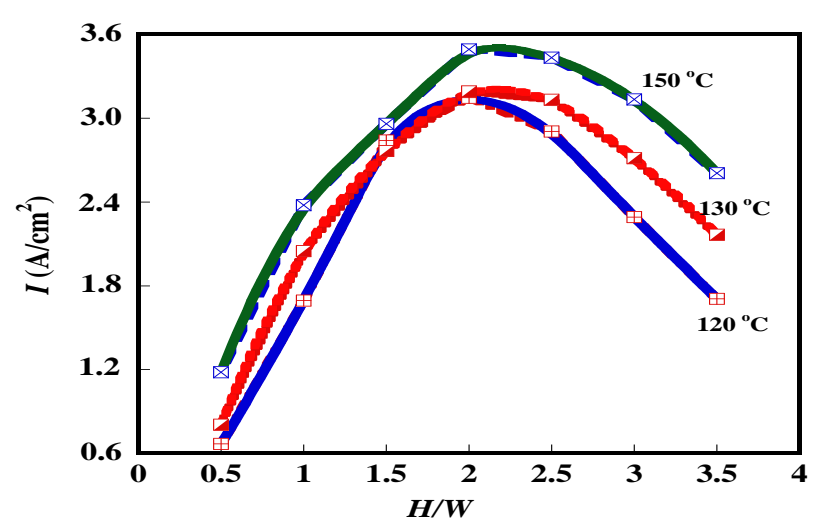

Figure 11. Effect of optimised cooling channel aspect ratio on the peak fuel cell current density at different temperatures

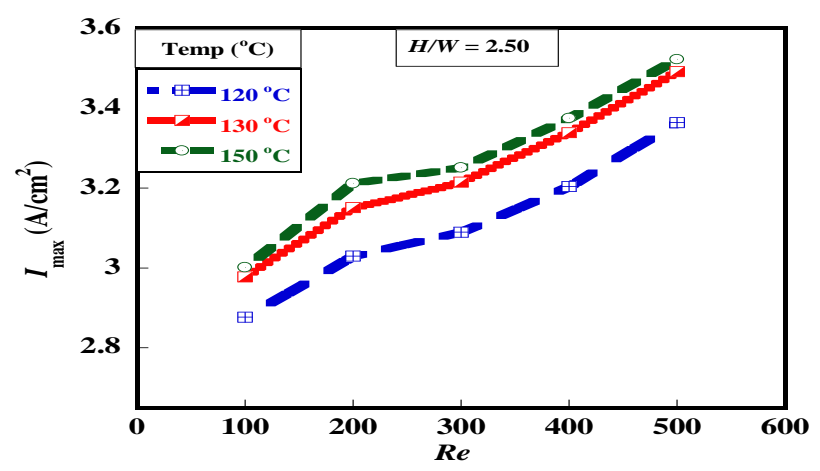

Figure 13. Effect of Reynolds number on the maximum current density at different cell temperature

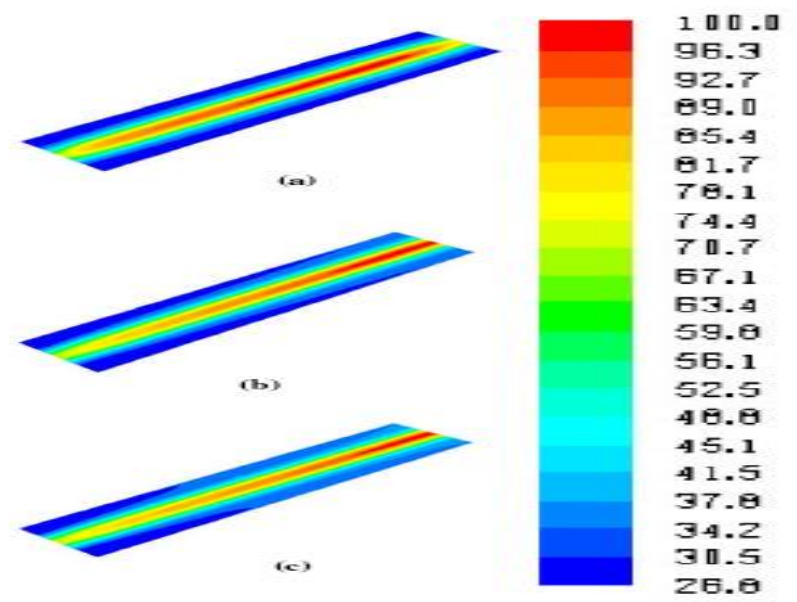

Figure 14. The local distribution of temperature along the membrane at different cooling channel aspect ratios and cell operating voltage of $0.7 \mathrm{~V}$ and $\mathrm{Re}=500$ : (a) $H / W=1.875$, (b) $H / W=2.500$ and (c) $H / W=$ 2.813.

Figure 13 shows the effect of the maximised fuel cell current density as a function of the cooling gas Reynolds number for fixed cell temperatures and a fixed cooling channel aspect ratio of $2.50 \mathrm{~mm}$. The

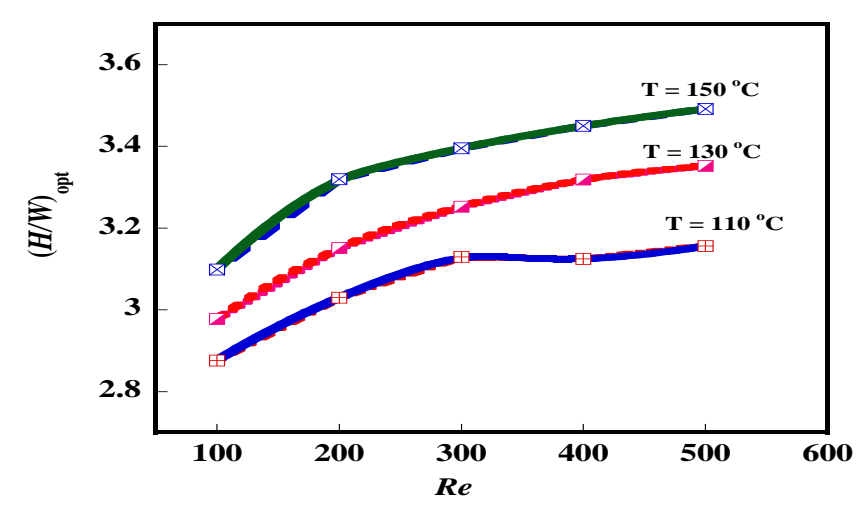

Figure 12. Effect of Reynolds number and temperature on the optimised aspect ratio of the cooling channel

maximised current density increases with an increase in the cooling channel Reynolds number.

In Figure 14, temperature contours on the membrane section of the fuel cell system are presented for varying cooling channel aspect ratios for a fuel cell voltage of 0.7 and a Reynolds number of 500. The result shows an improved temperature profile on the membrane section as the aspect ratio of the cooling channel increases for the examined cooling air Reynolds number.

\section{CONCLUSION}

The present study is aimed at developing a numerical approach to improving PEM fuel cell performance at elevated operating temperatures through the combination of operating parameters with cooling channel aspect ratios. Numerical results indicate that operating parameters such as the stoichiometry ratio, relative humidity and the cooling channel aspect ratio have a significant effect on fuel cell performance, primarily in determining the level of membrane dehydration of PEM fuel cells. Optimal values of the stoichiometry ratio, relative humidity and cooling channel aspect ratios were obtained by integrating a direct problem solver with an optimiser (Dynamic-Q). For the particular PEM fuel cell model operating conditions considered in this work, fuel cell performance is considerably enhanced when combining the studied parameters. Performance is more outstanding at temperatures between $120^{\circ} \mathrm{C}$ and $130^{\circ} \mathrm{C}$. The performance increment then declines gradually from $130^{\circ} \mathrm{C}$ to $150^{\circ} \mathrm{C}$. It should be noted that beyond $150^{\circ} \mathrm{C}$, there is no significant increase in cell performance. The result of this work further shows that maximised current density also exist for varying 
cooling channel aspect ratios of the fuel cell system. The result also shows the possibility of operating low temperature PEM fuel cells beyond the typical critical temperatures $\left(<80^{\circ} \mathrm{C}\right)$, by using the combined optimal of the stoichiometry ratio, relative humidity and cooling channel geometry without the need for special temperature resistant materials (which are additional cost) for the PEM fuel cell development. In addition some of the advantages of operating beyond the nominal temperature of PEM fuel cell can be achieved. This study can easily be extended to varying cooling channel geometries and scaled for application in PEM stack systems for enhanced PEM fuel cell performance.

\section{ACKNOWLEDGEMENT}

This work was supported by Africa Centre of Excellence in ICT-Driven Knowledge Park (OAK-PARK) O.A.U., IleIfe, a World Bank initiative.

\section{REFERENCES}

[1] Jung, H. M., Lee, W. Y., Park, J. S., Kim, C. S. "Numerical analysis of a polymer electrolyte fuel cell", International Journal of Hydrogen Energy, 29, 2004, pp 945-954.

[2] Du, L., Jana, S. C. "Highly conductive/graphite composites for bipolar plates in proton exchange membrane fuel cells". Journal of Power Sources, 172, 2007, pp 734-741.

[3] Um, S., Wang, C. Y., Chen, K. S. "Computational fluid dynamics modeling of proton exchange membrane fuel cells", Journal of the Electrochemical Society, 147(12), 2000, pp 44854493.

[4] Faghri, A., Guo, Z. "Challenges and opportunities of thermal management issues related to fuel cell technology and modelling", International Journal Heat Mass Transfer, 48, 2005, pp 3891-3920.

[5] Li, Q. F., He, R. H., Jensen, J. O., Bjerrum, N. J. "Approaches and recent development of polymer electrolyte membranes for fuel cells operating above $100{ }^{\circ} \mathrm{C}$, Chemical Material, 15, 2003, pp 4896-4915.

[6] Zhang, J. L., Xie, Z., Zhang, J. J., Tanga, Y. H., Song, C. J., Navessin, T., Shi, Z. Q., Song, D. T., Wang, H. J., Wilkinson, D. P., Liu, Z. S., Holdcroft, S. "High temperature fuel cells", Journal of Power Sources, 160, 2006, pp 872-891.

[7] Shao, Y. Y., Yin, G. P., Wang, Z. B., Gao, Y. Z. "Proton exchange membrane fuel cell from low temperature to high temperature: material challenges", Journal of Power Sources, 167,2007, pp 235-242.
[8] Li, Q. F., Rudbeck, H. C., Chromik, A., Jensen, J. O., Pan, C., Steenberg, T., Calverley, M., Bjerrum, N. J., Kerres, J. "Properties, degradation and high temperature fuel cell test of different PBI and PBI blend membranes", Journal of Membrane Science, 347, 2010, pp260-270.

[9] Zhang, Y. J, Ouyang, M. G., Luo, J. X., Zhang, Z., Wang, Y. J. "Mathematical modeling of vehicle fuel cell power system thermal management", $S A E, 1$, 2003, pp 11-46.

[10] Andrew, R., Li, X. G. "Mathematical modelling of proton exchange membrane fuel cells", Journal of Power Sources 2001; 102:82-96.

[11] Coppo, M, Siegel, N. P., von Spakovsky, M. R. “On the influence of temperature on PEM fuel cell operation", Journal of Power Sources, 159, 2006, pp 560-569.

[12] Yan, W-M., Chen, F., Wu, H-Y., Soong, C-Y., Chu, H-S. "Analysis of thermal and water management with temperature-dependent diffusion effects in membrane of proton exchange membrane fuel cell", Journal of Power Sources, 129, 2004, pp 127 137.

[13] Obayopo, S. O., Bello-Ochende, T., Meyer, J. P. "Three-dimensional optimisation of a fuel gas channel of a PEM fuel cell for maximum current density", International Journal of Energy Research, 37, 2013, pp 228-241.

[14] Ju, H., Meng, H., Wang, C. Y. "A single-phase, nonisothermal model for PEM fuel", International Journal of Heat Mass Transfer, 48, 2005, pp 13031315.

[15] Snyman, J. A. Practical mathematical optimization: an introduction to basic optimization theory and classical and new gradient-based algorithm, Springer, New York, 2005.

[16] Um, S., Wang, C. Y., Chen, K. S. “Computational fluid dynamics modeling of proton exchange membrane fuel cells", Journal of Electrochemical Society, 147, 2004, pp 4485-4493.

[17] Cheng, C. H., Lin, H. H., Lai, G. “Design for geometric parameters of PEM fuel cell by integrating computational fluid dynamics code with optimisation method",Journal of Power Sources, 165, 2007, pp 803-813.

[18] Mench, M. M. Fuel cell engines, John Wiley \& Sons, New Jersey, 2008.

[19] Tanda, G. "Heat transfer and pressure drop in a rectangular channel with diamond-shaped elements", International Journal of Heat Mass Transfer, 44, 2001, pp 3529-3541.

[20] Rodatz, P., Buechi, F., Onder, C., and Guzzella, L. "Operational aspects of a large PEFC stack under 
practical conditions", Journal of Power Sources, 128, 2004, pp 208-217.

[21] Maharudrayya, S., Jayanti, S., and Deshpande, A. P. "Pressure drop and flow distribution in multiple parallel-channel configurations used in protonexchange membrane fuel cell stacks", Journal of Power Sources, 157, 2006, pp 358-367.

[22] Ansys Fluent® 12.0 Users Guide Documentation, Ansys Inc., Southpointe, SAS, 2009.

[23] Kim, Y. B. "Study on the effect of humidity and stoichiometry on the water saturation of PEM fuel cells", International Journal of Energy Research, 36, 2012, pp 509-522.

[24] Fluent Inc., Gambit Version 6 Manuals, 2001.

[25] Pantakar, S. V. Numerical heat transfer and fluid flow, Hemisphere Publishing Corp., New York, 1980.

[26] Snyman, J. A., Hay, A. M. The DYNAMIC-Q optimization method: an alternative to SQP?'. Computer and mathematics with applications, 44, 2002, pp 1589-98.

[27] Obayopo, S. O., Bello-Ochende, T., Meyer, J. P. "Modelling and optimization of reactant gas transport in a PEM fuel cell with a transverse pin fin insert in channel flow", International Journal of Hydrogen Energy, 37 (13), 2012, pp 1028610298.
[28] Morris, R. M., Snyman, J. A., Meyer, J. P. "Jets in crossflow mixing analysis using computational fluid dynamics and mathematical optimization", AIAA Journal of Propulsion Power, 23(3), 2007, pp 618-628.

[29] Le Roux, W. G., Bello-Ochende, T., Meyer, J. P. "Operating conditions of an open and direct solar thermal Brayton cycle with optimised cavity receiver and recuperator", Energy, 36, 2011, pp 6027-6036.

[31] Meyer, J. P. "Constructal law in technology, thermofluid and energy systems, and in design education", Physics of Life Review, 8(3), 2011, pp 247-248.

[32] Tao, W. Q, Min, C. H., Liu, X. L, He, Y. L., Yin, B. H., Jiang, W. "Parameter sensitivity examination and discussion of PEM fuel cell simulation model validation Part I. Current status of modeling research and model development", Journal of Power Sources, 160, 2006, pp 359-373.

[33] Wang, L., Husar, A., Zhou, T., Liu, H. "A parametric study of PEM fuel cell performances", International Journal of Hydrogen Energy, 28, 2003, pp 1263-1272.

[34] Berning, T., Djilali, N.“A three-dimensional, multiphase, multicomponent model of the cathode and anode of a PEM fuel cell", Journal Electrochemical Society, 150(2), 2003, pp A1598-A1607. 